\title{
Coccoloba alnifolia Leaf Extract as a Potential Antioxidant Molecule Using In Vitro and In Vivo Assays
}

\author{
Luciana Fentanes Moura de Melo, ${ }^{1,2}$ Dayanne Lopes Gomes, ${ }^{2,3}$ Lucas Felipe da Silva, ${ }^{1}$ \\ Larissa Marina Pereira Silva, ${ }^{4}$ Marina Lopes Machado, ${ }^{5,6}$ Cesar Orlando Muñoz Cadavid, \\ Silvana Maria Zucolotto, ${ }^{4}$ Riva de Paula Oliveira, ${ }^{5}$ Deborah Yara Alves Cursino dos Santos, \\ Hugo Alexandre Oliveira Rocha, ${ }^{2}$ and Katia Castanho Scortecci ${ }^{1}{ }^{1}$
}

\footnotetext{
${ }^{1}$ Laboratório de Transformação de Plantas e Análise em Microscopia (LTPAM), Departamento de Bioquímica, Universidade Federal do Rio Grande do Norte (UFRN), Natal 59078-970, Brazil

${ }^{2}$ Laboratório de Biotecnologia de Polímeros Naturais (BIOPOL), Departamento de Bioquímica, Universidade Federal do Rio Grande do Norte (UFRN), Natal 59078-970, Brazil

${ }^{3}$ Instituto Federal de Educação, Ciência e Tecnologia do Piauí (IFPI), Campus de São Raimundo Nonato, São Raimundo Nonato 64770-000, Brazil

${ }^{4}$ Laboratório de Produtos Naturais e Bioativos (PNBio), Departamento de Farmácia, Universidade Federal do Rio Grande do Norte (UFRN), Natal 59010-180, Brazil

${ }^{5}$ Laboratório de Genética Bioquímica (LGB), Departamento de Biologia Celular e Genética, Universidade Federal do Rio Grande do Norte (UFRN), Natal 59078-970, Brazil

${ }^{6}$ Programa de Pós-graduação em Ciências Biológicas, Bioquímica Toxicológica, Departamento de Bioquímica e Biologia Molecular, Centro de Ciências Naturais e Exatas, Universidade Federal de Santa Maria, Camobi, 97105-900 Santa Maria, RS, Brazil

${ }^{7}$ Laboratório de Fitoquímica, Departamento de Botânica, Universidade de São Paulo (USP), São Paulo, SP 05508-090, Brazil
}

Correspondence should be addressed to Katia Castanho Scortecci; kacscort@yahoo.com

Received 6 June 2020; Revised 9 August 2020; Accepted 2 September 2020; Published 10 October 2020

Academic Editor: Ana Cipak Gasparovic

Copyright (C) 2020 Luciana Fentanes Moura de Melo et al. This is an open access article distributed under the Creative Commons Attribution License, which permits unrestricted use, distribution, and reproduction in any medium, provided the original work is properly cited.

\footnotetext{
The genus Coccoloba is widely used in traditional folk medicine, but few scientific data exist for this genus. The goal of this study was to characterise the chemical composition and antioxidant activities of C. alnifolia leaf extracts using in vitro and in vivo assays. Six extracts were obtained: hexane (HE), chloroform (CE), ethanol (EE), methanol (ME), water end extract (WEE), and water extract (WE). Thin-layer chromatography (TLC) analysis showed the presence of phenols, saponins, terpenes, and flavonoids. In vitro assays demonstrated substantial antioxidant potential, especially for polar extracts (EE, ME, WEE, and WE). Moreover, no toxic effects were observed on mammalian cell lines for most of the extracts at the concentrations evaluated. The nematode Caenorhabditis elegans was also used as an in vivo model for testing antioxidant potential. The EE and WE were chosen, based on previously obtained results. It was observed that neither the EE nor the WE had any toxic effect on C. elegans development. Additionally, the antioxidant potential was evaluated using tert-butyl hydroperoxide as a stressor agent. The EE increased the life span of $C$. elegans by $28 \%$ compared to that of the control, and the WE increased the range to $39.2-41.3 \%$. Highperformance liquid chromatography (HPLC-DAD) showed the presence of gallic acid, $p$-coumaric acid, and vitexin in the WE. Therefore, in vitro and in vivo data demonstrated the antioxidant potential of $C$. alnifolia extracts and their possible biotechnological applications.
} 


\section{Introduction}

Free radicals are produced as a normal part of metabolism by mitochondria, peroxisomes, phagocytosis, inflammatory processes, ischaemia, and physical exercise [1]. The balance between the production and neutralisation of reactive oxygen species (ROS) by antioxidant systems is very important, and an imbalance tends towards ROS overproduction leading to so-called oxidative stress $[2,3]$.

Additionally, cells are normally targets of reactive species such as reactive oxygen species (ROS), reactive nitrogen species (RNS), and reactive sulfur species (RSS). This imbalance may damage molecules such as proteins, lipids, DNA, and RNA and lead to metabolic disorders and diseases such as cancer, cardiovascular diseases, diabetes, atherosclerosis, stroke, neurological disorders, renal disorders, liver disorders, hypertension, and rheumatoid arthritis, among others associated with oxidative stress [2-5].

Plants produce a mixture of compounds known as secondary metabolites that have different biological and pharmacological properties. These secondary metabolites are known to have antioxidant potential that is important for maintaining this oxidative balance. These molecules may be obtained from different plant tissues such as leaves, bark, roots, and fruit [6]. Thus, the identification and isolation of compounds are important research topics in this field [7].

The Polygonaceae (Caryophyllales) has approximately 51 genera and 1100 species distributed throughout various biomes worldwide. Some species are used as ornamental plants, some are cultivated for medicinal purposes, and some are economically important for the supply of wood for the production of household items [8]. The genus Coccoloba consists of approximately 46 species. Of these, 21 are endemic to Brazil and distributed in several biomes: Amazon Forest, Atlantic Forest, Caatinga, Brazilian savanna (Cerrado), and Pantanal. Coccoloba plants have articulated stems, alternate and whole simple leaves, with concresced stipules, and arteries. They are herbaceous, shrubby, arboreal, or lianas [9].

The chemical composition for Coccoloba has been described; it contains triterpenes, diterpenes, anthraquinones, phytosteroids, alkaloid benzenoids, saponins, flavonoids, tannins, gallic acid, epigallocatechin, gallate, myristin-3-O-8rhamnoside, $\beta$-sitosterol, $\beta$-lupeol, ursolic and betulic acids, carboxylic acids, esters, aldehydes, ellagic acid, benzoic acid, $o$-coumaric acid, rutin, myricetin, and quercetin [10-12]. The species C. uvifera, C. cereifera, and C. mollis have been evaluated as larvicidal agents against Aedes aegypti mosquitoes [13], as well as antifungal [14], cytotoxic [15], antimicrobial [10], wood-biofungicidal, and phytopatogenic bacterial [12].

Coccoloba alnifolia, popularly known as "pau-de estalo" or "cabuçu," is one of the endemic Brazilian species of this genus. Despite all these uses in traditional folk medicine, there is no scientific information about the secondary metabolite composition of $C$. alnifolia nor about their possible biological activities. The goal of this study was to characterise the chemical composition and the antioxidant activities of $C$. alnifolia extracts using in vitro and in vivo models. Five leaf extracts were obtained through a serial extraction (using apolar solvents to polar solvents), and the sixth extract was made with only water (based on folk use). In general, these extracts did not affect the viability of six different mammalian cell lines. In addition, in vitro and in vivo assays showed four polar extracts, EE, ME, WEE, and WE, which were sources of antioxidant molecules. Moreover, EE and WE extracts did not affect the fecundity of Caenorhabditis elegans nematodes used as a test model. Therefore, Coccoloba alnifolia leaves have excellent potential for the development of herbal medicines and as antioxidant products.

\section{Materials and Methods}

2.1. Reagents. Potassium ferricyanide, ferrous sulfate II, trichloroacetic acid, and sulfuric acid were purchased from Merck (Darmstadt, Germany). Nitro blue tetrazolium (NBT), monosaccharides, diaminoethanetetraacetic acid (EDTA), D-glucose, acid gallic, ascorbic acid, bovine serum albumin protein, ascorbic acid, methionine, 3-(4,5dimethylthiazolyl-2)-2,5- diphenyltetrazolium bromide (MTT), pyrocatechol violet, riboflavin, ammonium molybdate, and tert-butyl hydrogen peroxide ( $\mathrm{t}-\mathrm{BOOH})$ were purchased from Sigma-Aldrich Co. (St. Louis, MO, USA). Sodium bicarbonate, nonessential amino acids, and phosphate-buffered saline (PBS) were purchased from Invitrogen Corporation (Burlington, ON, Canada). Dulbecco's Modified Eagle Medium (DMEM) and fetal bovine serum (FBS) were obtained from CULTILAB (Campinas, SP, Brazil). Penicillin and streptomycin were obtained from Gibco (Fort Worth, TX, USA). All other solvents and chemicals were of analytical grade from Synth (Diadema, SP, Brazil).

2.2. Plant Material. Coccoloba alnifolia mature leaves were harvested on May 2015 from a specimen located at the Parque das Dunas, Natal, RN, Brazil (UTM zone $250257315 \mathrm{~m}$ E $9357108 \mathrm{~m} \mathrm{~N}$-GPS Garmin Etrex). This region corresponds to the Atlantic Forest biome. After identification, a voucher was deposited in the UFRN Herbarium with number: UFRN 17133. The research was registered at SISBIO no. 54064-1, SISGEN no. A39FD4C.

2.3. Preparation of Extracts. After harvest, fresh leaves were divided into small pieces and transferred into a flask at a proportion of $1: 10(w / v)(100 \mathrm{~g}$ fresh leaves to $1000 \mathrm{~mL}$ of solvent) to be macerated during $24 \mathrm{~h}$ for each solvent used. A serial extraction approach was made using different solvents following the order from apolar to polar solvents like hexane (HE), chloroform (CE), ethanol (EE), methanol (ME), and water end extract (WEE). The approach used to prepare the extracts was a serial extraction using different solvents where the leaves were macerated, and it was added each solvent (apolar to polar solvents), for $24 \mathrm{~h}$. Then, leaves were filtered and moved back to the flask, and the next solvent was added. In this way, water end extract (WEE) corresponds to the last solvent used for this serial extraction. The idea of a serial extraction separated the compound based on the solvent. Furthermore, the extract made using only water-WE-was based on the folk used.

To prevent light degradation, the flask was covered with aluminum foil. Then, it was placed on a shaker table at 
$150 \mathrm{rpm}$ for $24 \mathrm{~h}$ at $24^{\circ} \mathrm{C}$ (Tecnal Shacker). The extract was filtered through Whatman No. 1 paper. Leaves were transferred back to the flask with the next solvent following the seriated extraction under the same conditions. The extracts were dried in a rotaevaporator (Tecnal-TE 210) at $40^{\circ} \mathrm{C}$. The extracts were recovered into 1\% DMSO (Merck), then lyophilized (Labconco FreeZone 4.5). All extracts were resuspended into water at a final concentration of $100 \mathrm{mg} / \mathrm{mL}$ (stock extract) and kept at $-18^{\circ} \mathrm{C}$ until use.

\subsection{Total Content of Sugar, Phenolic Compounds, and Protein}

2.4.1. Total Sugars. To verify the amount of sugars in the extracts, the phenol- $\mathrm{H}_{2} \mathrm{SO}_{4}$ method was used and the Dglucose (Sigma-Aldrich) as a standard. The total sugars were measured at $490 \mathrm{~nm}$ (Hitachi U-2000 Tokyo, Japan) [16].

2.4.2. Total Phenolic Compounds. The content of total phenolic compounds was measured using Folin Ciocalteu method, and gallic acid (Sigma-Aldrich) was used as standard. It was measured at $765 \mathrm{~nm}$ (BioTek Epoch Microplate, California, CA, USA) [17].

2.4.3. Total Soluble Proteins. Total protein content was measured using Bradford method, and bovine serum albumin protein (Sigma-Aldrich) was used as standard. The reaction was measured at $595 \mathrm{~nm}$ (BioTek Epoch Microplate, California, CA, USA) [18].

2.5. In Vitro Antioxidant Activity. Each antioxidant assay was done in triplicates and repeated three times. All readings were done using the spectrophotometer BioTek Epoch Microplate (California, CA, USA). The extracts from C. alnifolia were used at $250 \mu \mathrm{g} / \mathrm{mL}$.

2.5.1. Total Antioxidant Capacity (TAC). The antioxidant activity was measured considering the reduction of $\mathrm{Mo}^{+6}$ to $\mathrm{Mo}^{+5}$ by the plant extracts and subsequent formation of a green phosphate $/ \mathrm{Mo}^{+5}$ complex at acid $\mathrm{pH}$. The extract concentration used was $250 \mu \mathrm{g} / \mathrm{mL}$ that was mixed to the 600 $\mathrm{mM}$ sulfuric acidammonium molybdate), and it was incubated at $100^{\circ} \mathrm{C}$ for $90 \mathrm{~min}$ [19]. After this time, the mixture was kept at room temperature to cool down, and the absorbance was measured at $695 \mathrm{~nm}$. The results were compared to the negative control (distilled water). The total antioxidant capacity was expressed in equivalents of ascorbic acid (EAA/g).

2.5.2. DPPH. The antioxidant activity was determined by the ability of the antioxidants present in the samples to scavenging the radical DPPH [20]. The extract was added at concentration of $250 \mu \mathrm{g} / \mathrm{mL}$ and $100 \mu \mathrm{L}$ of DPPH $(0.1 \mathrm{mM})$. The mixture was mixed vigorously, and it was allowed to stand at room temperature during $30 \mathrm{~min}$. Then, the absorbance was then measured at $517 \mathrm{~nm}$. The blank control was ethanol 99.5\% (Synth, Brazil), and the negative control was distilled water. The DPPH scavenging activity was calculated as follows: Scavenging activity $(\%)=[(1-($ sample - blank $)) /$ negative control] $\times 100 \%$.
2.5.3. Reducing Power Assay. The reducing power of the samples were evaluated by the reduction of potassium ferricyanide into potassium ferrocyanide [21]. The plant extract at $250 \mu \mathrm{g} / \mathrm{mL}$ was added to a solution containing $0.2 \mathrm{M}$ phosphate buffer $(\mathrm{pH} 6.6)$ and potassium ferricyanide $(1 \% w / v)$ in a final volume of $4 \mathrm{~mL}$. The reaction was incubated at $50^{\circ} \mathrm{C}$ for $20 \mathrm{~min}$; after this period, it was stopped by adding the TCA solution $(10 \% w / v)$. The solution was then mixed with distilled water and ferric chloride $(0.1 \% w / v)$. The absorbance was measured at $700 \mathrm{~nm}$. Phosphate buffer was used as blank control. The result was expressed as a percentage of the activity presented by $0.1 \mathrm{mg} / \mathrm{mL}$ ascorbic acid (standard-Sigma-Aldrich).

2.5.4. Superoxide Scavenging Activity. The assay is based on the ability from the extracts to inhibit the photochemical reduction of nitroblue tetrazolium (NBT) into riboflavinlight-NBT system $[21,22]$. To do this, the extract at concentration of $250 \mu \mathrm{g} / \mathrm{mL}$ was added into $50 \mathrm{mM}$ phosphate buffer (pH 7.8), 13 mM methionine, $100 \mathrm{mM}$ EDTA, $75 \mathrm{mM}$ NBT, and $2 \mathrm{mM}$ riboflavin. After, the mixture, the solution was exposed for 10 minutes to a fluorescent lamp. The change of color to blue was due to formazan production, and it was monitored by absorbance at $560 \mathrm{~nm}$. In the spectrophotometer. EDTA was used as a control and distilled water as blank. Results were expressed as percent scavenging:

Percentage of superoxide scavenging
$\quad=([$ standard control - sample $] /[$ standard control - blank $]) \times 100$.

2.6. Cell Viability-MTT Assay. The effect of the C. alnifolia extracts was evaluated on cell viability. One nontumour cell line was used: NIH/3T3 (ATCC CRL-1658-a murine fibroblast) as well as five tumour cell lines: HeLa (ATCC CCL2-an adenocarcinoma cell of human uterus), SiHa (ATCC HTB-35-a human squamous cellular carcinoma cell), PC3 (ATCC CRL-1435-a human prostate adenocarcinoma cell), B16-F10 (ATCC CRL-6475-a mouse skin melanoma cell), and PANC-1 (ATCC CRL-1469-a pancreatic adenocarcinoma cells). First, cell lines were grown in culture flasks using the Dulbecco's Modified Eagle Medium (DMEM) supplemented with FBS $(10 \% v / v)$ and antibiotics $(100 \mathrm{U} / \mathrm{mL}$ penicillin and $100 \mu \mathrm{g} / \mathrm{mL}$ streptomycin). These culture flask were maintained in a humidified $5 \% \mathrm{CO}_{2}$ atmosphere at $37^{\circ} \mathrm{C}$. To evaluate the extract effect on cell viability, the cells were transferred into 96 -well plates at $5 \times 10^{3}$ cell per well until they reach the confluence. The extracts $(\mathrm{HE}, \mathrm{CE}, \mathrm{EE}$, $\mathrm{ME}, \mathrm{WEE}$, and AE) were added at $0,100,250$, or $500 \mu \mathrm{g} / \mathrm{mL}$ for $24 \mathrm{~h}$ at $37^{\circ} \mathrm{C}$ in a $5 \% \mathrm{CO}_{2}$ atmosphere. After the incubation period, the medium was changed to $100 \mu \mathrm{L}$ of MTT ( $1 \mathrm{mg} / \mathrm{mL}$ dissolved in DMEM). Then, cells were incubated for $4 \mathrm{~h}$ in a $5 \% \mathrm{CO}_{2}$ atmosphere at $37^{\circ} \mathrm{C}$. Next, the wells were aspirated, and formazan crystals were solubilized by the addition of $100 \mu \mathrm{L} /$ well ethanol $[23,24]$. Plate was read at $570 \mathrm{~nm}$ absorbance using an Epoch microplate spectrophotometer (BioTek Instruments Inc., Winooski, VT, USA). Cell viability was determined and compared to the negative control (only 
DMEM) using the following formula: \%viability $=\left(A_{\text {test }} /\right.$ $\left.A_{\text {control }}\right) \times 100$, in which $A_{\text {test }}$ corresponded to the absorbance of the experimental group, and $A_{\text {control }}$ was the absorbance of the negative control.

\subsection{In Vivo Antioxidant Activity}

2.7.1. Caenorhabditis elegans-Maintenance and Treatment. C. elegans N2 (wild-type line) were obtained from the Caenorhabditis Genetics Center (University of Minnesota, USA) and was maintained in nematode growth medium (NGM) seeded with Escherichia coli OP50 at $20^{\circ} \mathrm{C}$ according to Brenner [25]. Worms were synchronized using bleaching solution in gravid hermaphrodites $(\mathrm{NaOCl} 1 \%, \mathrm{NaOH} 0.25 \mathrm{M})$ to have animals at L1 stage (Sulston and Hodgkin, 1988). For treatment, EE and WEE extracts were filtered using a $0.22 \mu \mathrm{m}$ filter (Merck) and added to the NGM at final concentrations of either 1 or $10 \mathrm{mg} / \mathrm{mL}$. Synchronized L1 were cultivated on NGM plates containing extracts and seeded with E. coli OP50 for $48 \mathrm{~h}$ at $20^{\circ} \mathrm{C}$ until they reached L4 stage.

2.7.2. Toxicity on Caenorhabditis elegans Eggs. For this assay, 30 eggs were placed into three NGM plates containing EE and WEE at 0,1 , and $10 \mathrm{mg} / \mathrm{mL}$ and kept at $20^{\circ} \mathrm{C}$ for $48 \mathrm{~h}$. After this, the number of L4 and eggs were counted. This assay was done in three independent assays having a total number of 90 eggs/group.

2.7.3. Oxidative Stress Assay. The oxidative stress assay was performed using tert-butyl hydrogen peroxide ( $\mathrm{t}-\mathrm{BOOH})$ as a ROS producer $[26,27]$. Forty worms at L4 stage were treated with EE and WEE at concentrations 0, 1, and $10 \mathrm{mg} / \mathrm{mL}$ for $48 \mathrm{~h}$ at $20^{\circ} \mathrm{C}$. After that, worms were transferred to 12 -well plate having M9 buffer with $8 \mathrm{mM} \mathrm{t}$ $\mathrm{BOOH}$ and evaluated every half hour. Those worms that did not react to the stimulus were considered dead (no movement). Some worms were censored, which means when the worm was not found or it died for reasons other than the oxidative stress. These analyses were done in five independent assays.

2.8. Thin-Layer Chromatography (TLC). Chromatoplates of silica gel $F_{254}$ were used for the analyses. The mobile phases used were as follows: (i) ethyl acetate:formic acid:water $(8: 0.8: 1, v / v / v)$, (ii) ethyl acetate : formic acid:methanol:water $(10: 0.5: 0.6: 0.2, v / v / v / v)$, and (iii) toluene : ethyl acetate: formic acid $(5: 5: 0.5, v / v / v)$. Compound visualization was achieved by spraying solutions of sulfuric vanillin, $0.5 \%$ Natural A Reagent (difenilboriloxietilamina), 1\% ferric chloride in methanol, and Dragendorff. The standards used at TLC were as follows: quercetin, ursolic acid, gallic acid, isoquercetin, chlorogenic acid, ellagic acid, isoquercitrin, luteonin, canferol, rutin, caffeic acid, catechin, orientin, isoorientin, vitexin, and isovitexin (Sigma-Aldrich purity $\geq 95$ $\%)$. Then, the color was observed, and the retention factor (Rf) of spots measured and compared with literature [28]. For the ME and EE, a Co-TLC was done to confirm the presence of glycoside flavonoids vitexin and isovitexin.
2.9. High-Performance Liquid Chromatography (HPLC$D A D$ ). The WE was analysed by HPLC-DAD (Agilent 1260) equipped with a C18 column (Zorbax-150 mm $\times$ $4.6 \mathrm{~mm}$ i.d. $\times 3.5 \mu \mathrm{m})$. The elution was done with a gradient of $0.1 \%$ acetic acid (A) and acetonitrile (B) as follows: $10 \%$ B (0-6 min), 10 to $15 \% \mathrm{~B}$ (6-7 min), 15\% B (7-22 min), 15 to $50 \% \mathrm{~B}(22-32 \mathrm{~min}), 50$ to $100 \% \mathrm{~B}(32-42 \mathrm{~min})$, and $100 \% \mathrm{~B}(42-50 \mathrm{~min})$, at a constant flow rate of $1 \mathrm{~mL} / \mathrm{min}$. The sample was prepared at $1 \mathrm{mg} / \mathrm{mL}$ using methanol (HPLC grade), and the volume of injection was $3 \mu \mathrm{L}$. The column temperature was $45^{\circ} \mathrm{C}$, and detection was done at $228,254,280,290,320,340$, and $352 \mathrm{~nm}$. The identification of phenolic compounds was obtained by comparison of retention time and UV-visible absorption spectra with standard compounds.

The standards used in the HPLC-DAD were as follows: 3hydroxycinnamic acid (501-52-0), benzoic acid (65-85-0), caffeic acid (331-39-5), cinnamic 92 acid (621-82-9), chlorogenic acid (327-97-9), ellagic acid (476-66-4), ferulic acid (1135-93 24-6), gallic acid (149-91-7), gentisic acid (49079-9), o-coumaric acid (583-17-5), p-coumaric acid (50198-4), rosmarinic acid (20283-92-5), sinapic acid (530-596), apigenin (520-36-5), apiin-apigenin-7-(2-O-apiosylglucoside) (26544-34-3), kaempferol (520-18-3), kaempferol 3O-D-galactoside (23627-87-4), 3-O-methylkaempferol (1592-70-7), biorobin-kaempferol 3-O- $\beta$-robinobioside (17297-56-2), nicotiflorin-kaempferol 3-O- $\beta$ rutinoside (17650-84-9), catechin (154-23-4), chrysin-5,7-dihydroxyflavone (480-40-0), chrysoeriol-3'-O-methylluteolin (49171-4), daidzein-4,7-dihydroxyisoflavone (486-66-8), epicatechin (490-46-0), genistein-4',5,7-trihydroxyisoflavone (446-72-0), gossypetin-8-hydroxyquercetin (489-35-0), hesperidin (520-26-3), hesperitin (520-33-2), hispidulin-6methoxyapigenin (1447-88-7), homoorientin-luteolin 6-C$\beta$-D glucoside (4261-42-1), isorhamnetin 3-O- $\beta$-galactoside (6743-92-6), isorhamnetin 3-O- $\beta$-D-glucoside (5041-82-7), keioside-isorhamnetin 3-O-robinobioside (107740-46-5), narcissin-isorhamnetin 3-O- $\beta$ rutinoside (604-80-8), luteolin (491-70-3), myricetin (529-44-2), naringenin (480-41-1), neohesperidin (13241-33-3), orientin-luteolin 8-Cglucoside (28608-75-5), quercetagetin-7-O-glucoside (54875-4), quercetin (117-39-5), hyperin-quercetin 3-O- $\beta$ galactoside (482-36-0), isoquercetrin-quercetin 3-O- $\beta$-glucoside (482-35-9), quercetin 3-O- $\beta$-gentiobioside (7431-83$6)$, quercetin 3-O-robinobioside (52525-35-6), quercitrin-quercetin 3-O-rhamnoside (522-12-3), rhamnetin (90-19$7)$, rutin-quercetin $3-\mathrm{O}-\beta$-rutinoside (153-18-4), taxifolin-dihydroquercetin (480-18-2), tiliroside-kaempferol 3O-(6" -O-p-coumaroyl) glucoside (20316-62-5), and vitexi$\mathrm{n}$-apigenin 8-C114 glucoside (3861-93-4). Other standards correspond to the library made in the Phytochemistry Lab, Department of Botany, University of São Paulo.

2.10. Bioinformatics Analysis. Through TLC analyses, the presence of two glycoside flavonoids vitexin and isovitexin in C. alnifolia leaf extracts was observed. These compounds were used to search at the Traditional Chinese Medicine System Pharmacology (TCMSP) database for gene targets [29]. 
The data obtained at TCMSP were used at the Kyoto Encyclopedia Genes and Gnome (KEGG) database [30]. The pathways identified at KEGG were listed in descending order according to $p$ value. These data were used to build a network using String 10 version 11 (https://string-db.org/).

2.11. Statistical Analysis. All results were expressed as mean \pm standard. Each assay was done as a triplicate or a quintuplet, and each one was repeated at least 3 times. Statistical analysis was done using the GraphPad Prism 6.0 (GraphPad software Inc., San Diego, CA, USA), using the variation analysis (one-way ANOVA) and Tukey's post-test to compare the different groups. Differences that had $p$ values $\leq 0.05$ were considered significant.

\section{Results}

3.1. Total Content of Sugar, Phenolic Compounds, and Protein. Five extracts were obtained in a series from nonpolar to polar: hexane (HE), chloroform (CE), ethanol (EE), methanol (ME), and water end extract (WEE), and the sixth was made only with water-water extract (WE). Table 1 shows that the total phenolic compounds ranged from $2.3 \mu \mathrm{g} / \mathrm{g}$ to $61.26 \mu \mathrm{g} / \mathrm{g}$, in order $\mathrm{HE}<\mathrm{CE}<\mathrm{WE}<\mathrm{WEE}<\mathrm{EE}<\mathrm{ME}$. The sugar content ranged from $33.45 \mu \mathrm{g} / \mathrm{g}$ to $225.00 \mu \mathrm{g} / \mathrm{g}$, and the order was $\mathrm{CE}<\mathrm{HE}<\mathrm{WEE}<\mathrm{EE}<\mathrm{WE}<\mathrm{ME}$. The protein content was low ranging from 1.1 to $4.5 \mu \mathrm{g} / \mathrm{g}$.

3.2. In Vitro Antioxidant Activity. Considering the presence of phenolic compounds and understanding that these phytochemicals may be associated with antioxidant activity, the antioxidant potential of each of the six C. alnifolia extracts was analysed using four assays: total antioxidant capacity (TAC), DPPH (2,2-diphenyl-1-picryl-hydrazyl-hydrate) free radical method, reducing power test, and superoxide scavenging activity.

The TAC assay evaluated the ability of the sample to donate electrons and thus neutralise reactive species. The highest values of TAC were found for ME (111.38 EEAq $\mathrm{mg}$ ) and EE (96 EEAq mg). WEE (58.25 EEAq mg) and WE (59.89 EEAq $\mathrm{mg}$ ) presented equivalent results (Figure 1(a)). For the DPPH assay, the antioxidant activity ranged from $49 \%$ to $114 \%$ (Figure 1(b)). Moreover, polar extracts showed the highest activities for the reducing power assay, for which the values ranged from $83.9 \%$ to $105.4 \%$ (Figure 1(c)). A similar result was also observed for superoxide radical scavenging assay, where the highest values were observed for polar extracts, and these values ranged from $76.4 \%$ to $91 \%$ (Figure $1(\mathrm{~d})$ ).

Pearson coefficient analyses showed a positive correlation between the phenolic compound content of the C. alnifolia extracts and the antioxidant assays. There was a strong correlation between TAC and reducing power assay (Sup. Table 1), and a moderate correlation with superoxide radical scavenging. Furthermore, the sugar content presented a very strong correlation for reducing power assay and TAC and a moderate correlation with superoxide radical scavenging (Sup. Table 1).
TABLE 1: Total content of phenolics, proteins, and sugars in the extracts obtained from the leaves of C. alnifolia.

\begin{tabular}{lccc}
\hline Extracts & Sugar $(\mu \mathrm{g} / \mathrm{g})$ & $\begin{array}{c}\text { Phenolic } \\
\text { compounds } \\
(\mu \mathrm{g} / \mathrm{g})\end{array}$ & $\begin{array}{c}\text { Proteins } \\
(\mu \mathrm{g} / \mathrm{g})\end{array}$ \\
\hline Hexane (HE) & 34.35 & 2.30 & 1.4 \\
Chloroform (CE) & 33.45 & 10.54 & 1.1 \\
Ethanol (EE) & 183.81 & 44.95 & 3.9 \\
Methanol (ME) & 225.00 & 61.26 & 4.5 \\
Water end extract (WEE) & 128.60 & 33.63 & 2.8 \\
Water extract (WE) & 198.56 & 17.67 & 2.0 \\
\hline
\end{tabular}

3.3. In Vivo Analysis. The data from the antioxidant assays described above prompted us to perform antioxidant assays in vivo. However, before carrying out these assays, it was necessary to assess the toxic potential of these extracts to rule out a possible harmful effect on the animals used in the in vivo experiments. Then, their effects on the nontumour cells 3T3 and five tumour cell lines, HeLa, SiHa, PC-3, B16-F10, and PANC-1, were analyzed. After that, Caenorhabditis elegans was used as the in vivo model.

3.3.1. Cell Viability. For the cell lines, the effect of the six extracts on three concentrations $(100 \mu \mathrm{g} / \mathrm{mL}, 250 \mu \mathrm{g} / \mathrm{mL}$, and $500 \mu \mathrm{g} / \mathrm{mL}$ ) were evaluated (Figure 1). These extracts did not have any effect on cell viability at any of the three concentrations analysed. However, for the ME and WEE, a reduction in cell viability for nontumour cells of approximately $25 \%-35 \%$ was observed (ME at 250 or $500 \mu \mathrm{g} / \mathrm{mL}$ and for WEE at $500 \mu \mathrm{g} / \mathrm{mL}$ ) (Table 2). Furthermore, for tumour cell lines, in general, there was no significant change in cell viability. A reduction in cell viability ranging $10-25 \%$ for HE, CE, and WE was observed for HeLa and SiHa cell lines (Table 2). Thus, in general for nontumour and tumour cell lines, C. alnifolia extracts were not cytotoxic to the in vivo cell line model.

3.3.2. Toxicity of C. elegans Eggs. Caenorhabditis elegans has an impermeable cuticle, which is an extracellular matrix of collagen, forming a multifunctional exoskeleton, which makes the passage of substances difficult [31]. Because of this, higher extract concentrations were used compared to cell line assays. Considering the results obtained with antioxidants and with cell lines, the extracts, EE and WE, were selected for evaluation. For this model, 1 and $10 \mathrm{mg} / \mathrm{mL}$ extract concentrations were used to evaluate the possible toxic effect on egg hatching (Figure 2). Compared to the control, which had $70 \%$ egg hatching, both extracts, WE and $\mathrm{EE}$, had a similar effect at $1 \mathrm{mg} / \mathrm{mL}$ and $10 \mathrm{mg} / \mathrm{mL}$, ranging from $70 \%$ to $91 \%$ (Figure 2). Therefore, EE and WE did not have any toxic effect on egg hatching in the C. elegans model.

3.3.3. In Vivo Antioxidant Activity Using the C. elegans Model. Because the EE and WE extracts did not have toxic effects on egg hatching and embryo development, these extracts were investigated for their in vivo antioxidant effects in C. elegans. For these assays, wild animals (N2) were used 


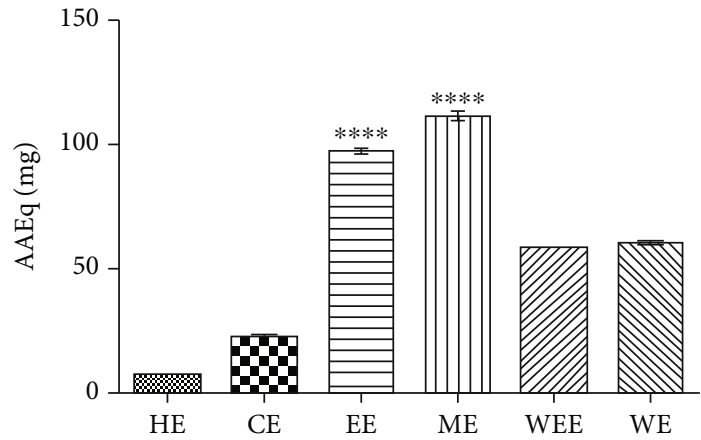

(a)

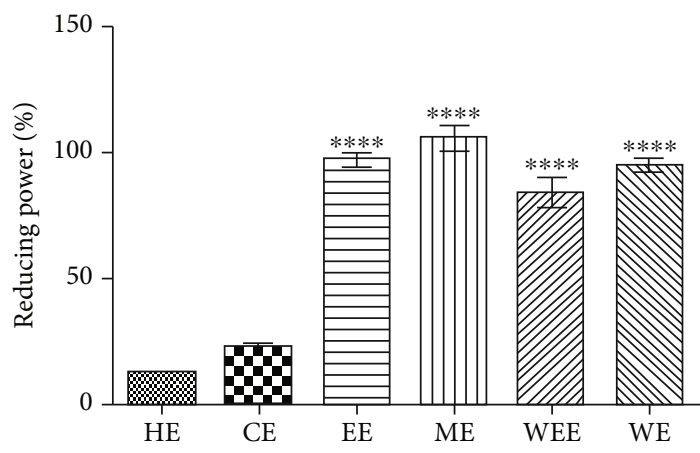

(c)



(b)

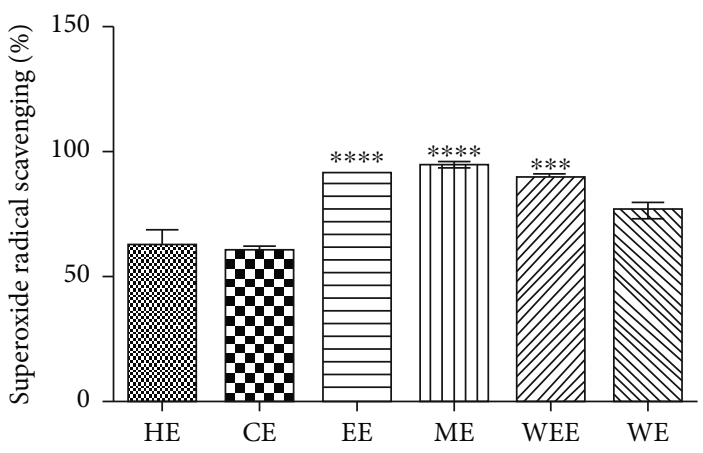

(d)

FIGURE 1: In vitro antioxidant activities using Coccoloba alnifolia extracts. (a) Total antioxidant capacity (TAC). The $x$-axis corresponds to different extracts, and the $y$-axis corresponds to the ascorbic acid equivalents in mg (AAEq mg). (b) Scavenging of the DPPH radical. The $x$-axis corresponds to different extracts used, and the $y$-axis corresponds to the percentage of DPPH scavenging. (c) Reducing power. The $x$-axis corresponds to different extracts, and the $y$-axis corresponds to the percentage of antioxidant activity. (d) Superoxide radical scavenging. The $x$-axis corresponds to different extracts, and the $y$-axis corresponds to percentage of antioxidant activity. For each assay the extract concentration used was $250 \mu \mathrm{g} / \mathrm{mL}$. HE: hexane extract; CE: chloroform extract; EE: ethanol extract; ME: methanol extract; WEE: water end extract; WE: water extract. Each assay was done in triplicate, and the assays were three times. The results were analyzed using an ANOVA and Tukey's test. ${ }^{* * *}$ Significant difference between extracts at $p<0.001$; ${ }^{* * *}$ Significant difference between the extracts at $p<0.01$.

and were treated with $\mathrm{EE}$ and $\mathrm{WE}$ at 1 and $10 \mathrm{mg} / \mathrm{mL}$. Subsequently, these worms were analysed for survival under oxidative stress conditions (treatment with tert-butyl hydroperoxide $(\mathrm{t}-\mathrm{BOOH}))$. An increased tolerance against oxidative stress conditions promoted by $\mathrm{t}-\mathrm{BOOH}$ treatment was observed with EE and WE treatments (Figures 3(a) and $3(\mathrm{~b})$ ). For the control animals in the EE treatments, the average survival time was $7.5 \mathrm{~h}$, compared with an average survival time of $10.5 \mathrm{~h}$ with $\mathrm{EE}(1 \mathrm{mg} / \mathrm{mL}$ and $10 \mathrm{mg} / \mathrm{mL})$, indicating an increase of $28.6 \%$ (Table 3 ).

For the control animals in the WE treatments, the average survival time was $4.8 \mathrm{~h}$ compared with $7.9 \mathrm{~h}$ and $8.2 \mathrm{~h}$ for $1 \mathrm{mg} / \mathrm{mL}$ and $10 \mathrm{mg} / \mathrm{mL} \mathrm{WE}$, respectively (Figure 3(b)). This difference represented an increase of $39.2 \%(1 \mathrm{mg} / \mathrm{mL})$ and $41.3 \%(10 \mathrm{mg} / \mathrm{mL})$ under $\mathrm{t}-\mathrm{BOOH}$ treatment (Table 4$)$.

\subsection{Phytochemical Compounds Identified by Thin-Layer} Chromatography (TLC). TLC analysis revealed that the presence of phenolic compounds such as flavonoids and their compounds may be associated with antioxidant activity observed in in vitro and in vivo assays. When the chromatoplates were revealed using sulphuric vanillin, colourful spots of saponins (CE, EE, ME, and $\mathrm{WE}$ ), and terpenes (CE, EE, and ME) were observed. Furthermore, the chromatoplates in contact with ferric chloride solution developed spots that suggested the presence of phenolic compounds in the polar extracts (EE, ME, WEE, and EE), and with the Natural A Reagent, the presence of flavonoids in the polar extracts was observed (EE, ME, WEE, and WE). In order to identify some compounds present in polar active extracts, standards were used in co-TLC analysis, and vitexin $(\mathrm{Rf}=0.51$, green fluorescent) and isovitexin ( $\mathrm{Rf}=0.40$, green fluorescent) were detected in the EE and ME. The presence of phenolic and flavonoids in all polar extracts, especially EE and ME, was observed.

3.5. WE Chemical Profile by HPLC-DAD. Based on the results observed with in vitro and in vivo assays for $\mathrm{EE}$ and WE and the traditional folk way of making extracts by maceration in water, we chose WE for further characterisation by highperformance liquid chromatography (HPLC-DAD), as TLC had shown the presence of vitexin and isovitexin.

The HPLC-DAD showed several peaks (Figure 4), which were evaluated at different UV spectra $(228-352 \mathrm{~nm})$. When 
TABLE 2: Effects of C. alnifolia extracts on cell viability using different concentrations (100, 250, and $500 \mu \mathrm{g} / \mathrm{mL})$ in nontumour and tumour cell lines after $24 \mathrm{~h}$ incubation.

\begin{tabular}{|c|c|c|c|c|c|c|c|}
\hline \multirow{2}{*}{ Extracts } & \multirow{2}{*}{ Conc. } & \multicolumn{6}{|c|}{ Cell lines $^{\#}$} \\
\hline & & NIH/3T3 & $\mathrm{HeLa}$ & $\mathrm{SiHa}$ & PC-3 & B16-F-10 & PANC-1 \\
\hline \multirow{3}{*}{$\mathrm{HE}$} & 100 & $120.68 \pm 27.23$ & $91.74 \pm 19.92$ & $75.59 \pm 20.75$ & $109.33 \pm 23.12$ & $139.64 \pm 26.79$ & $130.58 \pm 40.12$ \\
\hline & 250 & $124.83 \pm 44.05$ & $112.44 \pm 6.83$ & $83.15 \pm 12.66$ & $113.08 \pm 17.49$ & $145.54 \pm 23.01$ & $162.30 \pm 18.52$ \\
\hline & 500 & $188.97 \pm 15.68$ & $103.27 \pm 1.77$ & $95.68 \pm 14.30$ & $123.72 \pm 27.13$ & $104.56 \pm 30.87$ & $139.68 \pm 28.42$ \\
\hline \multirow{3}{*}{$\mathrm{CE}$} & 100 & $132.61 \pm 3.41$ & $74.26 \pm 1.91$ & $83.43 \pm 7.66$ & $117.07 \pm 5.83$ & $135.60 \pm 83.95$ & $113.97 \pm 10.64$ \\
\hline & 250 & $131.22 \pm 20.44$ & $101.68 \pm 12.80$ & $98.37 \pm 1.24$ & $116.21 \pm 11.43$ & $206.72 \pm 11.41$ & $145.28 \pm 10.74$ \\
\hline & 500 & $172.54 \pm 15.33$ & $99.22 \pm 17.64$ & $106.30 \pm 3.93$ & $132.68 \pm 31.85$ & $264.33 \pm 63.63$ & $158.97 \pm 0.17$ \\
\hline \multirow{3}{*}{$\mathrm{EE}$} & 100 & $130.19 \pm 3.63$ & $112.50 \pm 37.64$ & $105.33 \pm 7.79$ & $125.51 \pm 1.86$ & $84.69 \pm 6.51$ & $100.72 \pm 6.31$ \\
\hline & 250 & $117.57 \pm 28.21$ & $119.26 \pm 16.78$ & $120.36 \pm 20.10$ & $125.12 \pm 4.42$ & $123.01 \pm 18.46$ & $118.93 \pm 1.06$ \\
\hline & 500 & $100.45 \pm 30.10$ & $102.37 \pm 30.54$ & $122.24 \pm 8.19$ & $107.96 \pm 10.68$ & $120.18 \pm 11.19$ & $111.22 \pm 14.92$ \\
\hline \multirow{3}{*}{ ME } & 100 & $74.69 \pm 22.23$ & $88.57 \pm 2.58$ & $106.01 \pm 1.04$ & $122.33 \pm 6.68$ & $287.14 \pm 91.82$ & $138.11 \pm 28.11$ \\
\hline & 250 & $67.25 \pm 29.26$ & $100.40 \pm 3.89$ & $118.88 \pm 3.95$ & $114.25 \pm 7.24$ & $270.75 \pm 68.13$ & $124.17 \pm 7.75$ \\
\hline & 500 & $66.74 \pm 6.32$ & $74.26 \pm 14.01$ & $111.19 \pm 10.36$ & $99.12 \pm 3.92$ & $257.63 \pm 60.13$ & $137.70 \pm 72.86$ \\
\hline \multirow{3}{*}{ WEE } & 100 & $69.67 \pm 76.06$ & $95.81 \pm 11.21$ & $92.45 \pm 31.21$ & $125.24 \pm 7.60$ & $186.85 \pm 76.03$ & $126.62 \pm 40.25$ \\
\hline & 250 & $67.08 \pm 32.71$ & $109.16 \pm 30.89$ & $106.87 \pm 19.22$ & $121.37 \pm 2.20$ & $214.59 \pm 41.43$ & $151.70 \pm 55.60$ \\
\hline & 500 & $68.81 \pm 28.83$ & $83.49 \pm 20.88$ & $96.53 \pm 22.22$ & $100.87 \pm 14.13$ & $243.80 \pm 139.33$ & $145.63 \pm 37.60$ \\
\hline \multirow{3}{*}{ WE } & 100 & $109.96 \pm 60.34$ & $92.39 \pm 30.05$ & $103.31 \pm 8.57$ & $127.17 \pm 32.17$ & $133.90 \pm 21.36$ & $84.16 \pm 4.91$ \\
\hline & 250 & $68.81 \pm 34.60$ & $91.78 \pm 5.65$ & $119.19 \pm 12.50$ & $109.21 \pm 20.20$ & $155.70 \pm 50.79$ & $89.09 \pm 17.49$ \\
\hline & 500 & $70.37 \pm 16.51$ & $90.20 \pm 0.13$ & $99.35 \pm 13.43$ & $108.46 \pm 7.45$ & $170.46 \pm 71.85$ & $90.63 \pm 17.25$ \\
\hline
\end{tabular}

HE: hexane extract; CE: chloroform extract; EE: ethanol extract; ME: methanol extract; WEE: water end extract; WE: water extract. "NIH/3T3: ATCC CRL1658-murine fibroblast; HeLa: ATCC CCL-2-adenocarcinoma cell of human uterus; SiHa: ATCC HTB-35-human squamous cellular carcinoma cell; PC-3: ATCC CRL-1435-human prostate adenocarcinoma cell; B16-F10: ATCC CRL-6475-mouse skin melanoma cell; PANC-1: ATCC CRL1469-pancreatic adenocarcinoma cells.
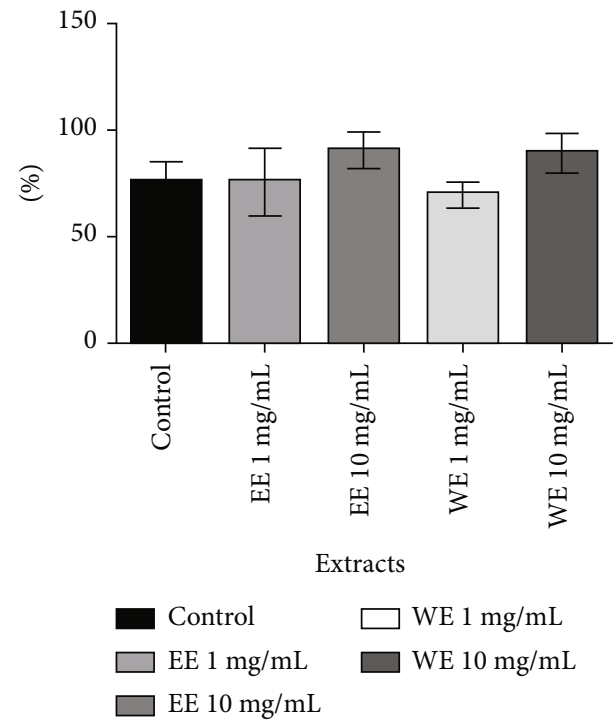

Figure 2: Percentage of the hatched eggs of $C$. elegans treated with extracts of $C$. alnifolia. The $x$-axis corresponds to the treatments with ethanol (EE) and water extract (WE) at $0 \mathrm{mg} / \mathrm{mL}$ (control), $1 \mathrm{mg} / \mathrm{mL}$, and $10 \mathrm{mg} / \mathrm{mL}$. The $y$-axis corresponds to the percentage egg hatching. Data were obtained in quintuplicate, and they were analysed by an ANOVA and Tukey's test with significance set at $p \leq 0.05$. compared to standards, peak \#2 corresponded to gallic acid $(\operatorname{tr}=2.000-280 \mathrm{~nm})$, peak \#16 corresponded to $p$-coumaric acid $(\operatorname{tr}=10.257-280 \mathrm{~nm})$, and peak $\# 19$ to vitexin $(\operatorname{tr}=13.576-280-352 \mathrm{~nm})$. The presence of vitexin was in agreement with the TLC data.

3.6. Bioinformatic Analysis. Bioinformatics is an excellent tool for data mining from potential targets considering the two bioactive molecules that were identified in the C. alnifolia extracts: vitexin and isovitexin. The Kyoto Encyclopedia of Genes and Genomes (KEGG) database was used to identify possible targets for these bioactive molecules. These molecules may be associated with pathways related to the immune system, cardiovascular disease, signalling pathways, cancer, nervous system, and others. More than 32 targets were observed (Table 5). When the overlap between targets was analysed, several gene targets such as IKBKB, PTGS2, RELA, TNF, MAPK7, AR, and NF-B were observed (Table 5 and Figure 5). Furthermore, the bioinformatics approach suggested that the bioactive molecules identified in C. alnifolia may have both antioxidant and anti-inflammatory activities.

\section{Discussion}

Coccoloba alnifolia has been used in folk medicine in northeastern Brazil, but there is no scientific information regarding 
Survival (t-BOOH)

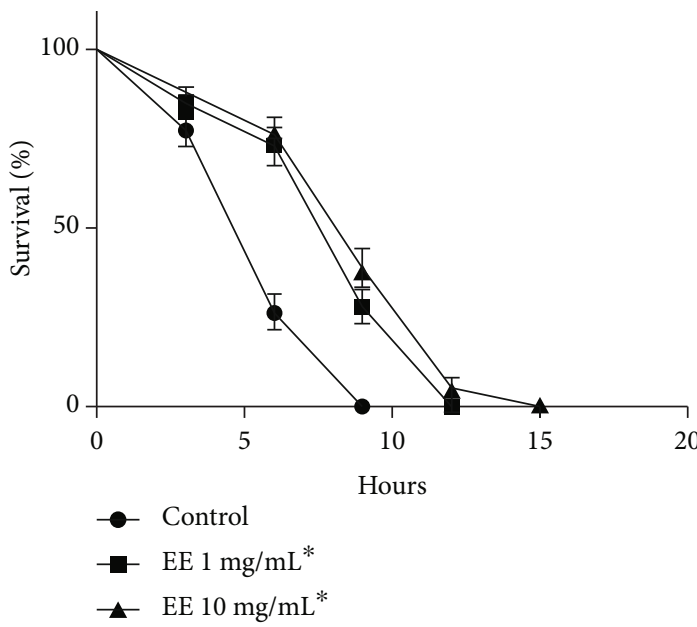

(a)
Survival (t-BOOH)

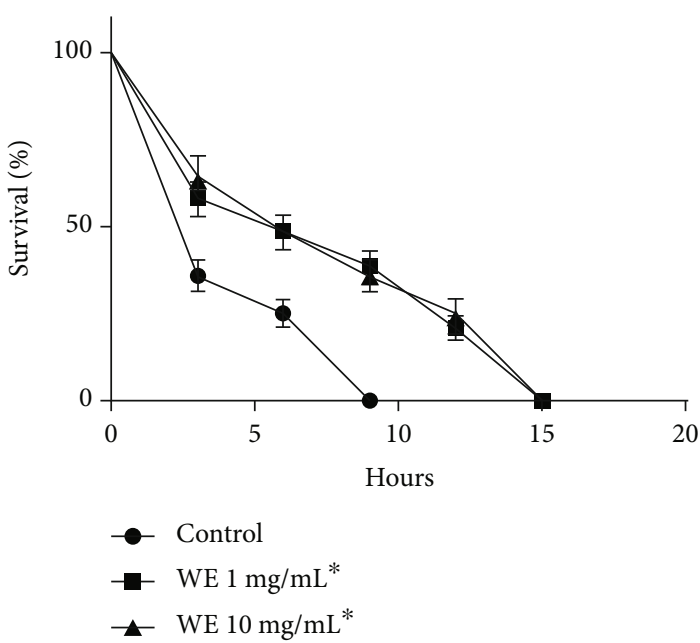

(b)

FIgURE 3: In vivo antioxidant activity of C. alnifolia extracts using the C. elegans model. (a) Survival assay of C. elegans worms treated with EE under oxidative stress treatment (t-BOOH). The EE treatment was with $0 \mathrm{mg} / \mathrm{mL}$ (control), $1 \mathrm{mg} / \mathrm{mL}$, and $10 \mathrm{mg} / \mathrm{mL}$ (b) Survival assay of $C$. elegans worms treated with WE under oxidative stress treatment (t-BOOH). The WE treatment was with $0 \mathrm{mg} / \mathrm{mL}(\mathrm{control}), 1 \mathrm{mg} / \mathrm{mL}$, and $10 \mathrm{mg} / \mathrm{mL}$. Survival for both treatments was observed every $3 \mathrm{~h}(3,6,9,12,15,18$, and $21 \mathrm{~h})$. Worms were maintained at $20^{\circ} \mathrm{C}$. The extract treatment was compared to the control by the Log-rank test $(p<0.0001)$. Data were collected in quintuplicate and were analysed by an ANOVA and the Tukey's test $(p \leq 0.05)$.

TABLE 3: Survival assay using C. elegans worm to measure the effect of EE extract on the lifetime.

\begin{tabular}{lcccc}
\hline Survival condition & $\begin{array}{c}\text { Mean of survival } \\
\text { time (hours) }\end{array}$ & $\begin{array}{c}\text { Variation of survival } \\
\text { mean (\%) }\end{array}$ & $\begin{array}{c}\text { p value-Log-rank } \\
\text { (Mantel-Cox) tests }\end{array}$ & $\begin{array}{c}\text { Number of dead } \\
\text { animals/censored }\end{array}$ \\
\hline Control & 7.5 & & $<0$ & $80 / 0$ \\
EE $1 \mathrm{mg} / \mathrm{mL}$ & 10.5 & 28.6 & $<0.001$ & $74 / 6$ \\
EE $10 \mathrm{mg} / \mathrm{mL}$ & 10.5 & 28.6 & $<0.0001$ & $80 / 0$ \\
\hline
\end{tabular}

TABLE 4: Survival assay using in vivo model-C. elegans model to evaluate the WE extract on lifetime.

\begin{tabular}{lcccc}
\hline Survival condition & $\begin{array}{c}\text { Mean of survival } \\
\text { time (hours) }\end{array}$ & $\begin{array}{c}\text { Variation of survival } \\
\text { mean (\%) }\end{array}$ & $\begin{array}{c}\text { p value-Log-rank } \\
\text { (Mantel-Cox) tests }\end{array}$ & $\begin{array}{c}\text { Number of dead } \\
\text { animals/censored }\end{array}$ \\
\hline Control & 4.8 & & & $80 / 0$ \\
WE $1 \mathrm{mg} / \mathrm{mL}$ & 7.9 & 39.2 & $<0.0001$ & $80 / 0$ \\
WE $10 \mathrm{mg} / \mathrm{mL}$ & 8.2 & 41.3 & $<0.0001$ & $80 / 0$ \\
\hline
\end{tabular}

its chemical composition or antioxidant activities. In this study, the chemical composition and biological activities of six leaf extracts were characterised using a series of solvents (apolar to polar serial approach) [32]. Chemical analyses showed the presence of sugars, proteins, and phenolic compounds. The proportion of these constituents varied among the extracts; EE, ME, WEE, and WE extracts contained high amounts of sugar and a moderate presence of phenolic compounds, whereas protein was very low in all the extracts.

Alam et al. [5] showed that polar solvents were good for extracting phenolic compounds, and the data presented here showed higher concentrations of phenolic compounds and flavonoids in these extracts (EE, WE, ME, WEE, and WE). TLC also showed the presence of terpenes (CE, EE, ME, and $\mathrm{WE}$ ) and saponins (CE, EE, ME, and WEE). In co-
TLC, the presence of vitexin and isovitexin was observed, while HPLC-DAD showed the presence of gallic acid, $p$-coumaric acid, and vitexin for WE. Although these compounds have been identified previously in other Coccoloba species $[10,33,34]$, our findings are the first to report their presence in C. alnifolia. Based on this, it is important to evaluate the antioxidant activity and other biological activities of C. alnifolia extracts that contain a mixture of bioactive molecules besides vitexin and isovitexin, which were identified by coTLC [35] and HPLC-DAD for WE.

The results obtained here showed excellent antioxidant potential for EE, ME, WEE, and WE, especially for reducing power and DPPH free radical scavenging. TAC showed higher antioxidant activity for EE and ME. DPPH evaluated the ability of a sample to scavenge DPHH free radicals, and 


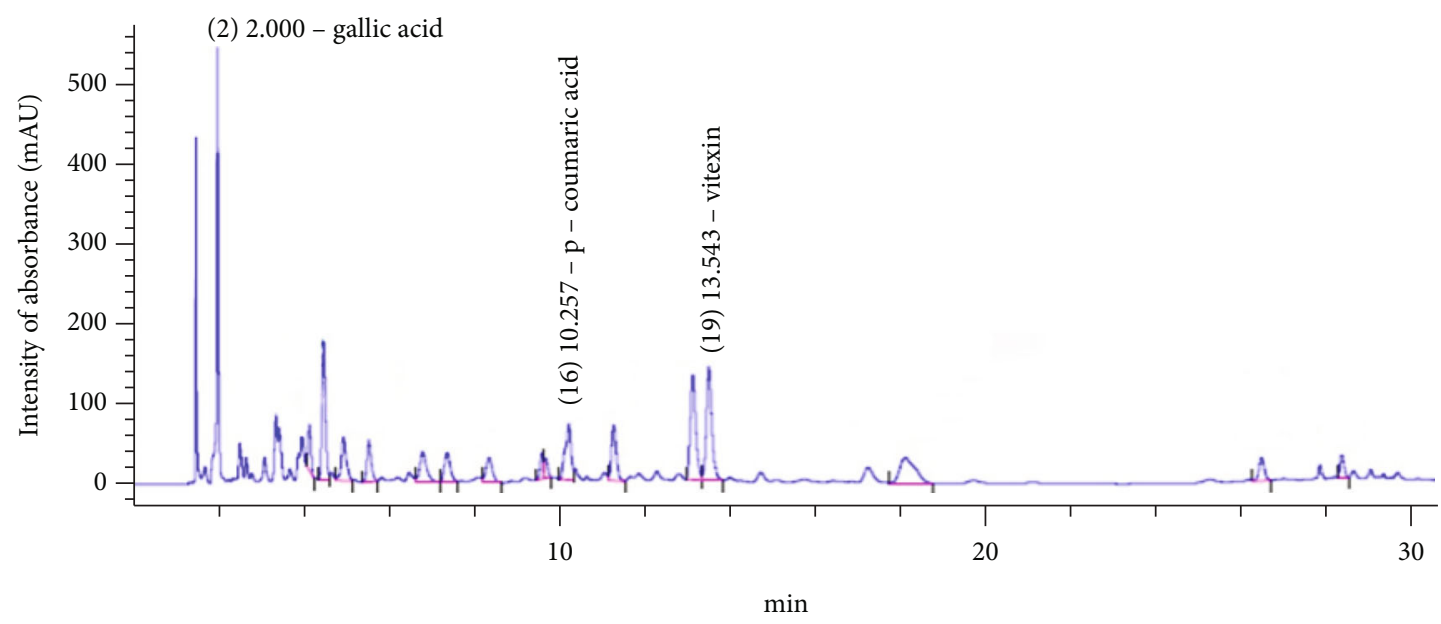

Figure 4: WE HPLC-DAD chromatogram. The WE analysis using HPLC-DAD. The 306 detection wavelength was set at $360 \mathrm{~nm}$, the $x$-axis corresponds to the retention times ( $\mathrm{min}$ ) of each peak, and the $y$-axis corresponds to the intensity of the peaks in mAU. The peak absorption spectra \#2 corresponds to gallic acid, \#16 to $p$-coumarin, and \#19 to vitexin.

TABLE 5: KEGG pathways and gene targets after the overlap analysis for vitexin and isovitexin.

\begin{tabular}{|c|c|c|c|}
\hline KEGG Brite (Homo sapiens) & Adjusted $p$ value & Corrected $p$ value & Related genes (targets) \\
\hline Immune system & $1.80 E-12$ & $2.36 E-10$ & IKBKB;PTGS2;RELA;TNF;MAPK7 \\
\hline Signal transduction & $1.37 E-09$ & $6.97 E-08$ & IKBKB;PTGS2;RELA;TNF; MAPK7 \\
\hline Cardiovascular disease & $4.96 E-09$ & $1.30 E-07$ & IKBKB;RELA;TNF;MAPK7 \\
\hline Drug resistance: antineoplastic & $1.68 E-08$ & $3.67 E-07$ & IKBKB;RELA;TNF \\
\hline Infectious disease viral & $3.30 E-08$ & $6.17 E-07$ & IKBKB;PTGS2;RELA;TNF \\
\hline Infectious disease: bacterial & $8.65 E-07$ & $5.67 E-06$ & IKBKB;RELA;TNF \\
\hline Infectious disease parasitic & $2.05 E-07$ & $2.24 E-06$ & PTGS2;RELA;TNF; IKBKB \\
\hline Endocrine system & $1.67 E-07$ & $2.08 E-06$ & IKBKB;RELA;TNF \\
\hline Signalling pathway & $1.74 E-07$ & $2.08 E-06$ & IKBKB;RELA;TNF \\
\hline Development and Regeneration & $1.02 E-06$ & $6.37 E-06$ & IKBKB;RELA;TNF \\
\hline Human disease: cancer & $4.00 E-07$ & $4.03 E-06$ & IKBKB;PTGS2;RELA; MAPK7 \\
\hline Endocrine and metabolic disease & $6.20 E-07$ & $4.77 E-06$ & IKBKB;RELA;TNF \\
\hline Nervous system & $8.24 E-07$ & $5.67 E-06$ & IKBKB;RELA;MAPK7 \\
\hline Cell growth and death & $1.22 E-06$ & $7.27 E-06$ & IKBKB;RELA;TNF \\
\hline
\end{tabular}

both reducing power and TAC assays analysed the ability of the sample to donate electrons. Gusman et al. [34] observed antioxidant activity using the DPPH assay for C. cereifera, and antioxidant activity using DPPH has also been observed for other species from Polygonaceae such as Rumex japonicus [36] and Polygonum maritimum [37]. These species have been used in traditional medicine in Asia, Europe, and Africa, reinforcing the data obtained here for C. alnifolia. The antioxidant potential may be associated with phenolic compounds as well as sugars present in the extract, as shown by Pearson's correlations. The sugars identified may be associated with phenolic compounds that are linked to sugar molecules, such as flavonoid glycosides, condensed tannins, and glycoside triterpenes, which may explain the presence of sugars in C. alnifolia extracts $[38,39]$. The antioxidant potential observed for these extracts may be associated with different bioactive molecules that might act to scavenge free radicals and reduce the ROS effects on cells, consequently maintaining the balance between production and degradation $[35,40,41]$.

In vitro assays showed that $C$. alnifolia had interesting antioxidant potential, and in vivo assays using cell lines showed that, in general, the six extracts were neither cytotoxic to 3T3 nontumour cell lines nor to Hela, SiHa, PC-3, B16-F10, and PANC tumour cell lines. On the other hand, Tsuboy et al. [15] observed that root extracts from C. mollis were more cytotoxic than leaf extracts against HTC tumour cell lines. He et al. [42] showed that vitexin and isovitexin are excellent antioxidant molecules and have a wide spectrum of antioxidant, antiproliferative, anti-inflammatory, and other properties. Moreover, it has been verified that extracts from $C$. uvifera and $C$. cereifera have proinflammatory activity and may act on tumour necrosis factor- $\alpha$ $(\mathrm{TNF}-\alpha)[33,34]$. The bioinformatics approach used here, 


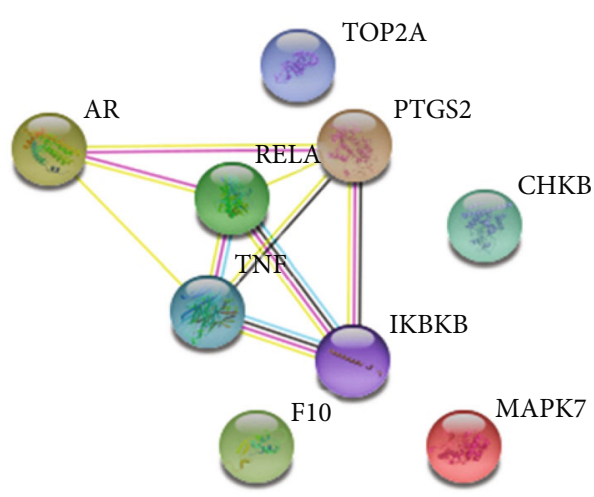

FIGURE 5: Schematic representation from an interactome using String 10 version 11 . This interactome showed the possible gene targets from vitexin and isovitexin, phenolic compounds presented at $C$. alnifolia extracts. The data obtained from KEEG were used to build a network using String 10 version 11. Each circle corresponds to a gene; the lines indicate how these genes are connected. The blue lines indicate the curated database, pink lines indicate the determined experimentally, yellow lines indicate the data from text mining, black lines indicate the coexpression, and green line indicates a gene neighbourhood.

considering the presence of vitexin and isovitexin, proposes that $C$. alnifolia extract may act on TNF- $\alpha$ and prostaglandin-endoperoxide synthase (PTGS or COX). Habtemariam [35] mentioned that extracts are a mixture of bioactive molecules that may act synergistically or alone. Furthermore, it has been observed that natural products may act on signalling pathways, for example, the NF- $\kappa \mathrm{B}$ signalling pathway [4, 35, 43-45]. Bioinformatics data using vitexin and isovitexin showed that some gene targets were antiinflammatory genes such as NF- $\kappa \mathrm{B}$ and COX-2.

Moreover, Caenorhabditis elegans has been shown to be an excellent model for identifying toxicity in chemical compounds. There are some assays that may show toxicity, such as egg hatching and nematode development [46, 47]. The results obtained showed that $\mathrm{EE}$ and WE were not toxic because they did not affect egg hatching, and these extracts had a protective effect against oxidative stress when t$\mathrm{BOOH}$ was used as a stressor agent. These extracts increased survival by $28 \%$ for $1 \mathrm{mg} / \mathrm{mL}$ EE, $31 \%$ for $1 \mathrm{mg} / \mathrm{mL} \mathrm{WE}$, and $42 \%$ for $10 \mathrm{mg} / \mathrm{mL}$ WE compared to that of the control animals. Yue et al. [48] observed that $p$-coumaric acid was able to reduce oxidative stress in $C$. elegans as well as increase its life span in oxidative stress conditions, similar to what was observed in EE and WE. Choubey et al. [49] showed different activities from gallic acid due to its antioxidant potential. Thus, $p$-coumaric acid, gallic acid, and vitexin may be some of the bioactive molecules present in our extract that have antioxidant potential and no toxicity, as observed in the data presented here for Coccoloba alnifolia extracts.

Other studies show phenolic compounds in the Coccoloba genus. Cota [10] working with C. acrostichoides identified betulin and $\beta$-sitosterol using TLC. Ashmawy et al. [12] working with C. uvifera leaves detected ellagic acid, benzoic acid, $o$-coumaric acid, rutin, myricetin, and quercetin in water, acetone, and ethanol extracts. Furthermore, for $C$. mollis triterpenes, diterpenes, anthraquinones, phytosteroids, and benzenes were identified in leaves and shoots [11].

For C. alnifolia, in the present study, phenolic compounds such as gallic acid, $p$-coumaric acid, vitexin, and isovitexin were observed, and HPLC-DAD showed that there are many other compounds to be identified. These extracts may have other bioactive molecules, which may act synergistically with phenolic compounds, resulting in oxidative protection, which reduces ROS effects and helps to maintain the redox balance (ROS production versus ROS degradation) in cells and tissues $[35,40]$. The data presented here show that EE and WE have great potential as natural antioxidant products.

\section{Conclusions}

Five Coccoloba alnifolia leaf extracts were obtained by serial extraction (using apolar solvents to polar solvents), and the sixth extract was made with only water (based on traditional folk use). The data obtained here show that these extracts contain phenolic compounds, terpenes, saponins, and flavonoids (vitexin and isovitexin). In in vitro and in vivo assays, four polar extracts, EE, ME, WEE, and WE, were shown to be sources of antioxidant molecules. In general, these extracts did not affect the viability of six different mammalian cell lines. Moreover, EE and WE did not affect the fecundity of Caenorhabditis elegans nematodes used as a test model and protected them against the $\mathrm{t}-\mathrm{BOOH}$ stressor, increasing their life span. Therefore, Coccoloba alnifolia leaves have excellent potential for the development of herbal medicines and as antioxidant products. Other biological activities may also be explored to determine how the potential antioxidants act in cells.

\section{Data Availability}

The data obtained in this study are available from the corresponding author upon request.

\section{Conflicts of Interest}

The authors have no conflicts of interest to declare.

\section{Authors' Contributions}

S.M.Z.L., R.P.O., H.A.O.R., and K.C.S. conceived and designed the experiments. L.F.M.M., D.L.G., L.F.S., L.M.P.S., M.L.M., C.O.M.C, S.M.Z.L., R.P.O., H.A.O.R., and K.C.S. performed the experiments, analyzed the data, and wrote the paper. All authors read and approved the manuscript.

\section{Acknowledgments}

The authors wish to thank to Coordenação de Aperfeiçoamento de Pessoal de Nível Superior (CAPES), Conselho Nacional de Desenvolvimento Científico e Tecnológico (CNPq), and Ministério da Ciência, Tecnologia e Inovação (MCTI) for financial support. The authors wish to thank to 
Aline Bertinatto Cruz from Laboratório de Fitoquímica, Departamento de Botânica, Universidade de São Paulo (USP) for helping us in HPLC-DAD analysis. H.A.O. R. and R.P.O. are a $\mathrm{CNPq}$ fellowship honoured researcher. L.F.M.M., L.M.P.S., and C.O.M.C. received a scholarship from CAPES.

\section{Supplementary Materials}

Supplementary Table 1 shows the Pearson coefficient analyses for sugar, protein, and phenolic compounds presented in each of the Coccoloba alnifolia extracts. The values obtained was shown in red, and it was considered a very strong correlation values higher than 0.9 , strong correlation values from 0.7 to 0.9 . The Pearson coefficient analyses showed a positive correlation between the phenolic compound content of the Coccoloba alnifolia extract and the antioxidant assay. There was a strong correlation between TAC and reducing power assay and a moderate correlation to superoxide radical scavenging. Furthermore, the sugar content presented a very strong correlation for reducing power assay and TAC and a moderate correlation with superoxide radical scavenging. (Supplementary Materials)

\section{References}

[1] V. Lobo, A. Patil, A. Phatak, and N. Chandra, "Free radicals, antioxidants and functional foods: impact on human health," Pharmacognosy Reviews, vol. 4, no. 8, pp. 118-126, 2010.

[2] D. Krishnaiah, R. Sarbatly, and R. Nithyanandam, "A review of the antioxidant potential of medicinal plant species," Food and Bioproducts Processing, vol. 89, no. 3, pp. 217-233, 2011.

[3] C. López-Alarcón and A. Denicola, "Evaluating the antioxidant capacity of natural products: a review on chemical and cellular-based assays," Analytica Chimica Acta, vol. 763, pp. 1-10, 2013.

[4] M. Carocho and I. C. F. R. Ferreira, "A review on antioxidants, prooxidants and related controversy: natural and synthetic compounds, screening and analysis methodologies and future perspectives," Food and Chemical Toxicology, vol. 51, pp. 1525, 2013.

[5] M. D. Nur Alam, N. J. Bristi, and M. D. Rafiquzzaman, "Review on in vivo and in vitro methods evaluation of antioxidant activity," Saudi Pharmaceutical Journal, vol. 21, no. 2, pp. 143-152, 2013.

[6] B. Armendáriz-Barragán, N. Zafar, W. Badri et al., "Plant extracts: from encapsulation to application," Expert Opinion on Drug Delivery, vol. 13, no. 8, pp. 1165-1175, 2016.

[7] P. Rajendran, N. Nandakumar, T. Rengarajan et al., "Antioxidants and human diseases," Clinica Chimica Acta, vol. 436, pp. 332-347, 2014.

[8] K. S. M. Sandra, L. . L. Anderson, D. . S. S. Naiane et al., "GCMS analysis of esterified fatty acids obtained from leaves and seeds of Triplaris gardneriana Wedd," African Journal of Pharmacy and Pharmacology, vol. 10, no. 30, pp. 623-630, 2016.

[9] E. de Melo, "As espécies de Coccoloba P. Browne (Polygonaceae) da Amazônia brasileira," Acta Amazonica, vol. 34, no. 4, pp. 525-551, 2004.
[10] B. Barros Cota, "Antimicrobial activity and constituents of Coccoloba acrostichoides," Fitoterapia, vol. 74, no. 7-8, pp. 729-731, 2003.

[11] P. E. S. Oliveira, W. S. . Santos, L. M. Conserva, and R. P. . L. Lemos, "Constituintes químicos das folhas e do caule de Coccoloba mollis Casaretto (Polygonaceae)," Revista Brasileira de Farmacognosia, vol. 18, pp. 713-717, 2008.

[12] N. A. Ashmawy, M. Z. M. Salem, N. E. Shanhorey, A. A. Al-Huqail, H. M. Ali, and S. I. Behiry, "Eco-friendly woodbiofungicidal and antibacterial activities of various Coccoloba uvifera L. leaf extracts: HPLC analysis of phenolic and flavonoid compounds," BioResources, vol. 15, no. 2, pp. 41654187, 2020.

[13] P. V. Oliveira, J. C. Ferreira Jr., F. S. Moura et al., "Larvicidal activity of 94 extracts from ten plant species of northeastern of Brazil against Aedes aegypti L. (Diptera: Culicidae)," Parasitology Research, vol. 107, no. 2, pp. 403-407, 2010.

[14] I. B. de Barros, J. F. de Souza Daniel, J. P. Pinto, M. I. Rezende, R. B. Filho, and D. T. Ferreira, "Phytochemical and antifungal activity of anthraquinones and root and leaf extracts of Coccoloba mollis on phytopathogens," Brazilian Archives of Biology and Technology, vol. 54, no. 3, pp. 535-541, 2011.

[15] M. S. Tsuboy, J. C. Marcarini, R. C. Luiz et al., "In vitro evaluation of the genotoxic activity and apoptosis induction of the extracts of roots and leaves from the medicinal plant Coccoloba mollis (Polygonaceae)," Journal of Medicinal Food, vol. 13, no. 3, pp. 503-508, 2010.

[16] M. DuBois, K. A. Gilles, J. K. Hamilton, P. A. Rebers, and F. Smith, "Colorimetric method for determination of sugars and related substances," Analytical Chemistry, vol. 28, no. 3, pp. 350-356, 1956.

[17] Y. Athukorala, K.-N. Kim, and Y.-J. Jeon, "Antiproliferative and antioxidant properties of an enzymatic hydrolysate from brown alga, Ecklonia cava," Food and Chemical Toxicology, vol. 44, no. 7, pp. 1065-1074, 2006.

[18] M. M. Bradford, "A rapid and sensitive method for the quantitation of microgram quantities of protein utilizing the principle of protein-dye binding," Analytical Biochemistry, vol. 72, no. 1-2, pp. 248-254, 1976.

[19] P. Prieto, M. Pineda, and M. Aguilar, "Spectrophotometric quantitation of antioxidant capacity through the formation of a phosphomolybdenum complex: specific application to the determination of vitamin E," Analytical Biochemistry, vol. 269, no. 2, pp. 337-341, 1999.

[20] K. Shimada, K. Fujikawa, K. Yahara, and T. Nakamura, “Antioxidative properties of xanthan on the autoxidation of soybean oil in cyclodextrin emulsion," Journal of Agricultural and Food Chemistry, vol. 40, no. 6, pp. 945-948, 1992.

[21] J. Wang, Q. Zhang, Z. Zhang, and Z. Li, “Antioxidant activity of sulfated polysaccharide fractions extracted from Laminaria japonica," International Journal of Biological Macromolecules, vol. 42, no. 2, pp. 127-132, 2008.

[22] N. Dasgupta and B. De, "Antioxidant activity of Piper betle L. leaf extract in vitro," Food Chemistry, vol. 88, no. 2, pp. 219224, 2004.

[23] T. Mosmann, "Rapid colorimetric assay for cellular growth and survival: application to proliferation and cytotoxicity assays," Journal of Immunological Methods, vol. 65, no. 1-2, pp. 55-63, 1983.

[24] R. F. Melo-Silveira, G. P. Fidelis, M. S. S. P. Costa et al., "In vitro antioxidant, anticoagulant and antimicrobial activity 
and in inhibition of cancer cell proliferation by xylan extracted from corn cobs," International Journal of Molecular Sciences, vol. 13, no. 1, pp. 409-426, 2012.

[25] S. Brenner, "The genetics of Caenorhabditis elegans," Genetics, vol. 77, no. 1, pp. 71-94, 1974.

[26] A. Scheschonka, M. E. Murphy, and H. Sies, “Temporal relationships between the loss of vitamin E, protein sulfhydryls and lipid peroxidation in microsomes challenged with different prooxidants," Chemico-Biological Interactions, vol. 74, no. 3, pp. 233-252, 1990.

[27] F. Aparecida Paiva, L. de Freitas Bonomo, P. Ferreira Boasquivis et al., "Carqueja (Baccharis trimera) protects against oxidative stress and $\beta$-amyloid-induced toxicity in Caenorhabditis elegans," Oxidative Medicine and Cellular Longevity., vol. 2015, 15 pages, 2015.

[28] H. Wagner and S. Bladt, Plant Drug Analysis: A Thin Layer Chromatography Atlas, Springer, Dordrecht ; NY, USA, 2009.

[29] J. Ru, P. Li, J. Wang et al., "TCMSP: a database of systems pharmacology for drug discovery from herbal medicines," Journal of Cheminformatics, vol. 6, no. 1, p. 13, 2014.

[30] M. Kanehisa, M. Furumichi, M. Tanabe, Y. Sato, and K. Morishima, "KEGG: new perspectives on genomes, pathways, diseases and drugs," Nucleic Acids Research, vol. 45, no. D1, pp. D353-D361, 2017.

[31] I. L. Johnstone, "The cuticle of the nematode Caenorhabditis elegans: a complex collagen structure," BioEssays, vol. 16, no. 3, pp. 171-178, 1994.

[32] A. R. C. Ribeiro, M. L. . S. Cordeiro, L. M. P. Silva et al., "Myrciaria tenella (DC.) O. Berg (Myrtaceae) leaves as a source of antioxidant compounds," Antioxidants, vol. 8, no. 8, p. 310, 2019.

[33] C. Bailey, K. R. Christian, S. Pradhan, M. G. Nair, and O. E. Christian, "Anti-inflammatory and antioxidant activities of Coccoloba uvifera (Seagrapes)," Phytochemistry, vol. 10, 2011.

[34] G. S. Gusman, P. R. V. Campana, L. C. Castro, R. O. Castilho, M. M. Teixeira, and F. C. Braga, "Evaluation of the effects of some Brazilian medicinal plants on the production of TNF$\alpha$ and CCL 2 by THP- 1 cells," Evidence-Based Complementary and Alternative Medicine, vol. 2015, 11 pages, 2015.

[35] S. Habtemariam, "Going back to the good old days: the merit of crude plant drug mixtures in the 21 st century," Internationa Journal of Complementary \& Alternative Medicine, vol. 6, no. 2, 2017.

[36] A. A. Elzaawely, T. D. Xuan, and S. Tawata, "Antioxidant and antibacterial activities of Rumex japonicus HOUTT. Aerial parts," Biological \& Pharmaceutical Bulletin, vol. 28, no. 12, pp. 2225-2230, 2005.

[37] I. A. El-Haci, F. A. Bekkara, W. Mazari, F. Hassani, and M. A. Didi, "Screening of biological activities of Polygonum maritimum L. from Algerian coast," Asian Pacific Journal of Tropical Biomedicine, vol. 3, no. 8, pp. 611-616, 2013.

[38] I. I. Mahmoud, M. S. A. Marzouk, F. A. Moharram, M. R. El-Gindi, and A. M. K. Hassan, "Acylated flavonol glycosides from Eugenia jambolana leaves," Phytochemistry, vol. 58, no. 8, pp. 1239-1244, 2001.

[39] A. K. Timbola, B. Szpoganicz, A. Branco, F. D. Monache, and M. G. Pizzolatti, "A new flavonol from leaves of Eugenia jambolana," Fitoterapia, vol. 73, no. 2, pp. 174-176, 2002.

[40] Y.-J. Zhang, R.-Y. Gan, S. Li et al., "Antioxidant phytochemicals for the prevention and treatment of chronic diseases," Molecules, vol. 20, no. 12, pp. 21138-21156, 2015.
[41] N. S. Mohd Sairazi and K. N. S. Sirajudeen, "Natural products and their bioactive compounds: neuroprotective potentials against neurodegenerative diseases," Evidence-Based Complementary and Alternative Medicine, vol. 2020, 30 pages, 2020.

[42] M. He, J.-W. Min, W.-L. Kong, X.-H. He, J.-X. Li, and B.W. Peng, "A review on the pharmacological effects of vitexin and isovitexin," Fitoterapia, vol. 115, pp. 74-85, 2016.

[43] S. Y. Lee, E. Moon, S. Y. Kim, and K. R. Lee, "Quinic acid derivatives from Pimpinella brachycarpa exert antineuroinflammatory activity in lipopolysaccharide-induced microglia," Bioorganic \& Medicinal Chemistry Letters, vol. 23, no. 7, pp. 2140-2144, 2013.

[44] M. Li, B. Li, Y. Hou et al., "Anti-inflammatory effects of chemical components from GINKGO BILOBA L. male flowers on lipopolysaccharide-stimulated RAW264.7 macrophages," Phytotherapy Research, vol. 33, no. 4, pp. 989-997, 2019.

[45] M. Soukhtanloo, E. Mohtashami, A. Maghrouni et al., "Natural products as promising targets in glioblastoma multiforme: a focus on NF- $\kappa$ B signaling pathway," Pharmacological Reports, vol. 72, no. 2, pp. 285-295, 2020.

[46] P. R. Hunt, “The C. elegans model in toxicity testing," Journal of Applied Toxicology, vol. 37, no. 1, pp. 50-59, 2017.

[47] P. H. Harlow, S. J. Perry, S. Widdison et al., "The nematode Caenorhabditis elegans as a tool to predict chemical activity on mammalian development and identify mechanisms influencing toxicological outcome," Scientific Reports, vol. 6, no. 1, article 22965, 2016.

[48] Y. Yue, P. Shen, Y. Xu, and Y. Park, "p-Coumaric acid improves oxidative and osmosis stress responses in Caenorhabditis elegans," Journal of the Science of Food and Agriculture, vol. 99, no. 3, pp. 1190-1197, 2019.

[49] S. Choubey, L. R. Varughese, V. Kumar, and V. Beniwal, "Medicinal importance of gallic acid and its ester derivatives: a patent review," Pharmaceutical Patent Analyst, vol. 4, no. 4, pp. 305-315, 2015. 